\title{
THE PROBLEMS OF A CLOSE SEASON FOR DEER
}

\author{
By G. Kenneth Whitehead
}

In April, 1952, the Poaching of Deer (Scotland) Bill was discussed and had a second reading in the House of Lords. Although the Bill provided for penalties of $£ 20$ for a first offence on summary conviction and a fine of $£ 100$, or two years' imprisonment, or both, in cases of conviction on indictment, there were two apparent weaknesses to which attention was called-namely that the powers to arrest poachers were given only to policemen, and secondly that the Bill did not include a close season for deer. Unfortunately this Bill was among the four Government Bills which were crowded out before the summer session ended, and since then, so far as I am aware, has not been included in any subsequent projected legislation.

In the meantime, however, a Deer (Close Season) Committee has been appointed by the Secretary of State for Scotland, and during the past year has been meeting in Edinburgh, under the Chairmanship of Sheriff R. H. Maconochie, with the following remit :-

"To consider the desirability of introducing a close season or seasons for deer in Scotland and the manner in which, and the safeguards for agricultural and other interests under which, any close season or seasons they may recommend should be made effective ; and to report."

The report of this Committee is still awaited.

While deer have always been considered a pest from the farmer's point of view, it must be conceded that there are many parts of this country-particularly in Scotland-which are fit for nothing more than deer forests. It is in the interests of all that every bit of land should produce as much food as possible in the most economical way. Venison, while it can obviously never compete with mutton or beef, is a small but valuable contribution from land that is unsuitable for supporting, throughout many months of the year, other forms of life. There is no doubt that venison is a valuable commodity-otherwise the deer poacher would not be able to find such a ready market at perhaps $£ 20$ per carcase for his ill-gotten gains-nor would the Government, I think, have sanctioned the Scottish Reindeer Project. The red deer population of Scotland to-day stands at about 200,000 , and every year it is probable that about 16,000 deer (stags and hinds) are killed. Provided these deer are all shot at the correct time of the year, that is to say, stags in the autumn 
and hinds in mid-winter-this number of carcases is sufficient to supply close on a thousand tons of good venison. This is a far greater tonnage of meat than I can ever visualize becoming available from the reindeer project.

The problem of deer is, undoubtedly, a far greater one to-day than it has ever been. Before the war deer forests were easily let and generally were better looked after than to-day. Deer were regularly fed and there were several stalkers and ghillies available to help keep them in the forest. Even when they did wander-as deer will always do in winter and spring-they offered little or no temptation to the commercial poacher, for there was then such a small demand for venison.

To-day, however, it is a different story. There are fewer stalkers to look after the deer; there is no artificial winter feeding; but worst of all, many of the deer, due to afforestation or to flooding in connection with hydro-electric schemes, are now being deprived of their ancient winter feeding grounds. They have to go somewhere, so local migrations have taken place. This has caused an extra burden on the winter feeding capacity of certain areas, and in consequence marauding by deer in some areas will be more apparent to-day than before the war. The excessive slaughter of deer in some areas has had a similar effect, and many forests that are easily accessible by road or water have lost practically all their stock of deer.

The chief opponents to the close season for deer are the blackface sheep farmers, and during the past few years a number of tenant farmers have protested that deer have done great damage to their unenclosed sheep grazing. It is worthy of note that in the great majority of cases when asked to substantiate their accusations they have been unable to show proof of damage. The crux of the matter seems to be this. Many of the complainants believed that if sufficiently vigorous protests were made the clause in the 1948 Agriculture (Scotland) Act, which allows tenant farmers to kill deer on their enclosed land and to sell the carcases for their own profit, would be extended to allow them to do likewise on unenclosed hill grazings. In other words, deer shooting is an attractive sideline, but it is only when hunger and cold drive the deer from the hills that the chance to turn their plight into hard cash is offered to the sheep farmers. It is not, I think, fully appreciated by those who only know the proud stag of the autumn, to what pitiful a condition a severe winter will reduce him. Two winters ago, for instance, collie dogs had to be used by the Blair Atholl stalkers to herd the deer away from arable land in Glen Tilt. 
Some of the male deer were so weak that they were only able to go a short distance without lying down for a breather. Throughout Scotland thousands of deer perished that winter. 'To take advantage of deer under such conditions is quite contrary to the tradition of sportsmanship for which Britain has for so long prided herself. A close season would stop this sort of thing. It would also give deer some respite for breeding, when the hinds could give proper attention to their calves.

Provided, of course, that a deer is killed humanely with a rifle there is nothing essentially cruel in killing, say, a stag or a hind in March or April. It is, however, being just utterly wasteful of something that if killed a few months earlier, would have made excellent meat. Far more serious, however, is the fact that when hunger drives the deer from the tops they herd together in the glens and alongside the roads. They are, therefore, extremely vulnerable not only to the poacher but also to the unscrupulous owner or tenant who, at any time, is able to organize a deer drive, and by indiscriminate shooting into the mass of deer with any type of weapon available, cause endless wounding and suffering. Before the war it was exceptional to see a wounded deer on the hill when stalking. Now, in many forests, it is an everyday occurrence. I think far too much stress has been laid on the damage done to deer by poachers. Just as much damage is done by proprietors who allow their tenants to shoot deer by such driving methods during the spring.

It is surprising to find how much opposition there is to a close season for deer solely on the grounds that any such scheme would be violated and prove unworkable. Are we so behindhand in our ability to enforce a law of the country that we cannot at least copy something which, for years, has been operated quite successfully in the majority of countries abroad? Suggestions for its enforcement are numerous, and of course, controversial, but I would suggest :-

(1) Formation of Deer Control Associations (which we will call, for convenience, D.C.A.s) in every county in which deer are present. (Several counties already have such associations.)

(2) Heavy fines for poaching, i.e. at least $£ 50$ for a first offence and confiscation of all equipment used.

(3) Heavy fines for killing deer during the close season without the D.C.A.s permission. It may, at times, be necessary in certain areas to issue such out-of-season permits in 
order to combat marauding. Such a scheme works in Sweden in relation to damage by elk where the hunting season only extends to about five days.

(4) More interest should be taken by owners in deer stocks. Each D.C.A. ought to institute an annual census in its county: February or March would be the best months, for at this time of the year the herds are more concentrated and sexes still distinguishable by the antlers of the stags.

(5) Deer carcases should be tagged-such a scheme works in Germany and also in U.S.A. I believe. This is a sealed aluminium tag which can be fixed by means of special pliers to an ear or limb of a carcase and can only be removed by the seal being broken.

(6) Retailers must be licensed to deal in deer carcases and must only accept tagged carcases during specified months. Offenders should be heavily fined and their licences withdrawn.

(7) The tags, serially numbered, could be issued by the D.C.A.s to each forest owner, who before the season would write to his D.C.A. and inform it that he had decided to kill " $X$ " number of stags and " $Y$ " number of hinds during the forthcoming season. Tags would be issued accordingly. At the end of the season he would then make a return to the D.C.A. to say how many deer had actually been killed; return any unused tags and advise the D.C.A. to which retailer the carcases had been sent. At a specified date each dealer in venison would also be required to return the tags he had removed from carcases to the appropriate D.C.A.

(8) Grading of deer carcases might be considered. This would help to prevent out-of-season stags being disposed of as " hind "flesh.

(9) I consider that the unrestricted privilege at present granted under the 1948 Agriculture (Scotland) Act to crofters to kill deer on enclosed ground should be repealed. This would automatically deprive the sheep farmer of unenclosed land all claims to enjoy the same privilege. The latter now rents his ground in the full knowledge that deer are likely to come on to it in winter and it is only since venison prices have soared that he has realized that he is missing the opportunity of running a profitable winter side-line. 
If a close season became operative, then obviously there must be suitable machinery for dealing with marauding deer. I would suggest, therefore, that the farmer should contact the D.C.A. which would give sanction immediately for the offending deer to be killed, preferably by the stalker or stalkers of the nearest deer forest. When this had been done the D.C.A. would issue the necessary number of tags and give instructions for the disposal of the deer. Deer killed out of season should automatically become the property of the D.C.A. and the sale of the carcases would help to defray expenses. If there was some such system for dealing with marauding deer, then I consider that in addition to repealing the section of the Agriculture (Scotland) Act of 1948 whereby deer may be shot on enclosed land, it would also be wiser to alter the existing provision in the same Act which prohibits the killing of deer between the hours of darkness, so as to legalize it on enclosed lands only. The hours of darkness are the very time the deer do their marauding and it is preferable that the offenders should be tackled on the spot and in the act.

These are but a few of the problems that this most controversial subject presents. From a cruelty point of view shooting at deer with shot guns-it is hardly shooting of deer, because the percentage of kills per shot is so negligible-causes far more suffering than any lack of a close season, and I believe that the two problems, a close season and the prohibition of shotguns, should be tackled concurrently. This latter view was also suggested by the Home Office Committee on Cruelty to Wild Animals who, in their Report published in 1951, observed "Our view is that the shooting of deer with shotguns must inevitably be accompanied by a great deal of suffering ".

\section{FIELD RESEARCH ON BRITISH BATS}

\section{By Michael Blackmore}

Comparatively little work has been done to ascertain the distribution and habits of British bats. Much of the data in standard works on mammals is scanty and some of the more detailed accounts of habits appear to have been based on behaviour in captivity, which may vary considerably from that of bats in their natural environment.

Before the distribution of our twelve native species can be worked out in detail one must be able to recognize the distinc- 